\title{
138. 99mTc-MAA肺血流SPECTの3D画像DATAを用いたVOLUME测定
}

Estimation of the lung perfusion volume using the 3D-image of Tc-99m-MAA lung SPECT

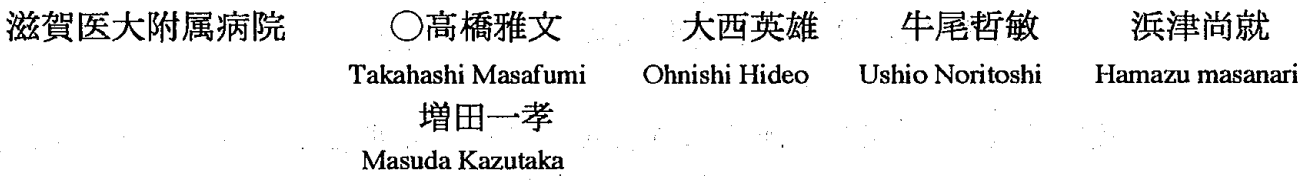

【目的】肺切除術の術前術後の肺血流機能を評価する為にSPECTのtransaxial data から肺の3D 表示及びVolumeを計測して血流機能を視覚化及び定量的に評価することを試みた。

【方法】RI画像においてはCT,MR画像のように明確な輪郭の判別が困難である。そこで既知容

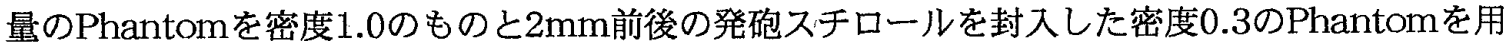
いてmax. countを基準としたcut off值を用いて闒值を実験的に決定した。画像処理装置として はwork station TITAN750 にonlineで画像データを転送しVolume Rendering のデータとして cutt off値以上を任意の值でマークしたmark dataからピクセル数を求めることでVolumeを計測 した。また肺を想定した同容量のPhantomを 2 つ使用し、一方の核種濃度を変えて実験した。 収集は128、mag1.25、360度、collimatorはLEHRを用いた。【結果及び考察】max. count を 基準とした cut off 值は密度0.3でmax.の34\%の值で既知の容量と一致、密度 $1.0 て ゙ は \operatorname{max.の45\% ~}$ で一致し密度依存性があった。この依存性は散乱線が增加したために画像がぼけcut off值を高く 設定しなければならないことを意味している。また同容量のphantomの一方の核種濃度を順次 低くした実験では希釈しないPhantomのmax值が基準となるので希釈したPhantomの容積は正 確に求められない。そこで画像を左右別々に抽出しそれぞれのmax. countのcut off值で Volumeを求めた。Table1 Volumeはどの濃度においても数值上は正確だがFig.1の3D画像を比 較すると希釈率が高くなるほど画質が粗くなりノイズも表示されるので50\%迄が限界だといえる。 相対濃度はmax. count比で正確に求められるので機能としてのVolume計測も可能となり、また 画像構築の際に機能低下した部分を発色を変えることで形態的にも機能的にも視覚的な表現が可 能となった。次に画像のhistogramの分散から閥値を求める大津の判別分析法を用いて比較を行っ た。大津の方法では密度 $1.0 て ゙ V o l u m e$ 比が1.07、密度 $0.3 て ゙ は 1.02$ と密度低存性がmax. countの cut off法より少ないが核種濃度の低下に対してはmax. countを基準とした方法より劣うていた。 しかし両者の利点を利用して誤差の少ない健側を大津の方法で評価し機能低下した術側の機能を max. count のcut off法を用いればより有効な方法となりえる。【まとめ】肺切除後の肺血流機 能の評価として今回の方法は有用であった。Fig.2 そして将来的には多くの臨床データをもとに 手術に対する術後のシュミレーションも可能であると思われた。

\begin{tabular}{|c|c|c|c|}
\hline & \multicolumn{2}{|c|}{ 英容国1150cc } & 必度 1.0 \\
\hline \multirow{2}{*}{ 相対溜度 } & \multicolumn{2}{|c|}{ max. cut off 法 } & 大津の判別法 \\
\hline & Volumett & 相对䇾度 & Volumett \\
\hline $\begin{array}{l}1.00 \\
(0.4 \mathrm{MBq} / \mathrm{cc})\end{array}$ & 1.01 & 1.00 & 1.07 \\
\hline 0.74 & 1.01 & 0.71 & 1.12 \\
\hline 0.59 & 0.99 & 0.57 & 1.15 \\
\hline 0.49 & 0.99 & 0.49 & 1.18 \\
\hline 0.42 & 0.97 & 0.42 & 1.25 \\
\hline 0.37 & 1.00 & 0.36 & 1.23 \\
\hline
\end{tabular}
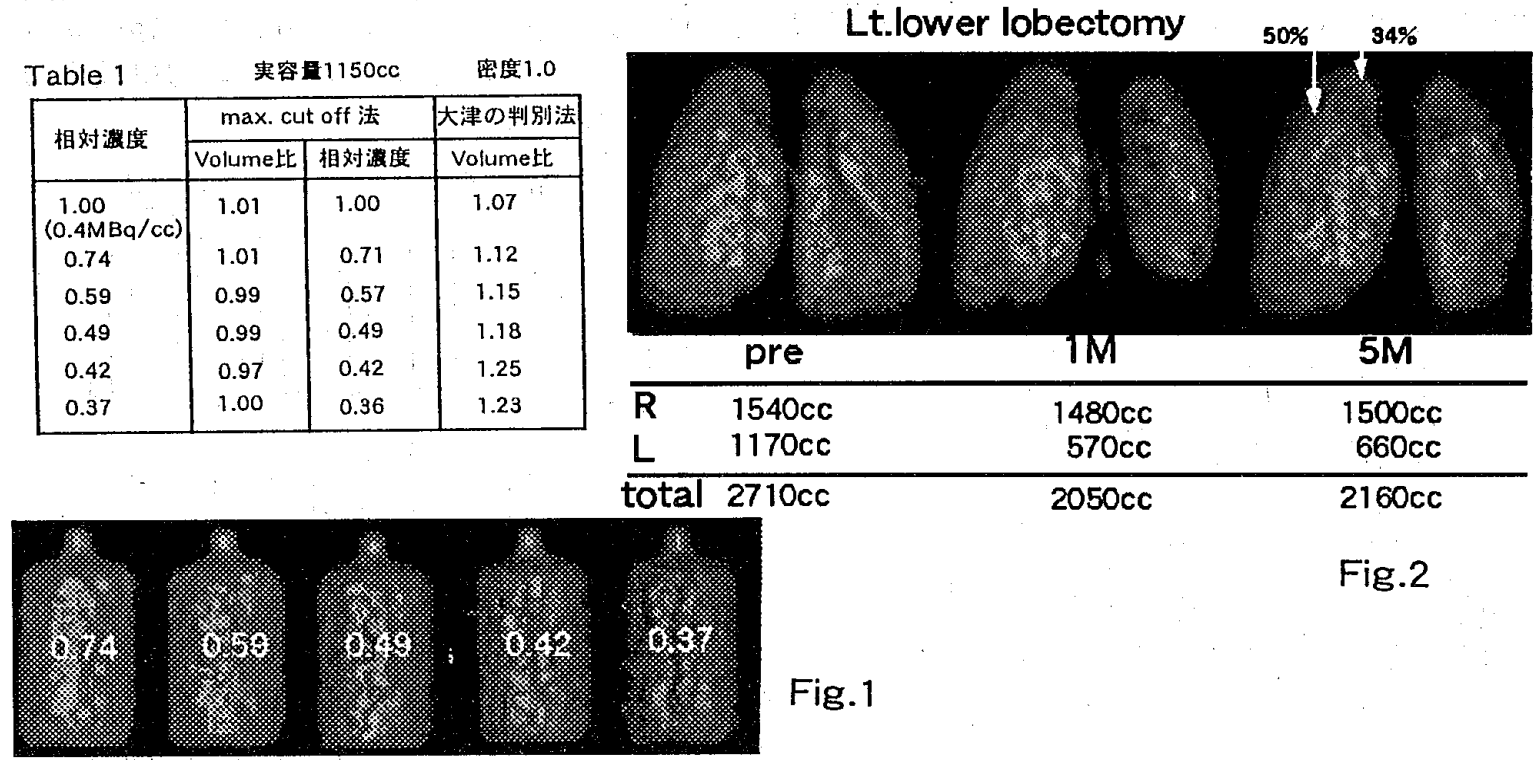

Fig.2

Fig.1 